\title{
Antoine Ó Flatharta's Elviad: from Grásta i Meiriceá to Grace in America
}

\author{
By John L. Murphy \\ DeVry University
}

\begin{abstract}
Copyright (c) 2006 by John L. Murphy. This text may be archived and redistributed both in electronic form and in hard copy, provided that the author and journal are properly cited and no fee is charged for access.
\end{abstract}

\begin{abstract}
Antoine Ó Flatharta bilingually charts media-saturated global impacts upon Galway's Gaelic-speakers. His play in Irish, Grásta i Meiriceá (1990) features two young Irishmen who journey by bus on a pilgrimage to Elvis' Graceland. In its 1993 English adaptation, Grace in America, the pair meets relatives who emigrated to 1940s Buffalo. Reading these plays by applying Seamus Deane's "primordial nomination," Edward Said's "cartographical impulse," Declan Kiberd's "spiritual tourism," and sociolinguistics, their relevance sharpens. In transforming Grásta into Grace, Ó Flatharta foreshadows his own shift into publishing in English. The fate of the play's mutating Irish vernacular, as shown in Ó Flatharta's drama, becomes less lamented than might be supposed. America, and English, represent liberation for his characters, in his work not only in English butunexpectedly-in his other native language of Irish.
\end{abstract}

Keywords: Antoine Ó Flatharta, Irish-language drama, Elvis Presley: drama, Linguistic codeswitching, English-language versions of Irish-language drama, Tourism, Emigration, Globalization/ Mass Media.

This Conamara-born writer bilingually charts media-saturated global impacts. His 1990 play in Irish, Grásta i Meiriceá, features two young men who journey by bus on a pilgrimage to Elvis' Graceland. In its English adaptation, Grace in America, the pair meets an aunt and uncle who emigrated to 1940s Buffalo. Disenchanted on their secular trek to Presley's shrine, the Conamara tourists realize how their Irish identity mixes indigenous with imported, through Native American legacies vs. massproduced song, film, and stereotypes: "America of the imagination" vs. St. Elvis' "holy well."

This play, published only in Irish, remains the sole Ó Flatharta drama reworked into English. He based it upon his own 1984 visit by Greyhound to Memphis. In Irish, Grásta appeared in theatre and on television. In English, Grace has been performed and revised between 1993 and 2001 in America,

ISSN 1699-31
London, and Scotland. I will introduce the macaronic Béarla agus Gaeilge delivery of Grásta-apparently unknown to the later play's English-language critics- as a multicultural context within which to explore Grace's innovations as Ó Flatharta revamped his play for international, theatrical, and linguistic reception.

Grásta $i$ Meiriceá graphs the odyssey of Seán and Finbarr, two emigrants in their twenties. Recently arrived in New York, working in the building trade, they speak for an Americanised generation prepared from birth to leave Ireland. Unnerved as illegals, they risk a road trip in part to evade arrest. Grásta being untranslated, my summation follows.

Finbarr, eager and ambitious, contrasts with Seán, cautious and skeptical. As they travel to the South by bus, both characters soon forget Conamara.. Finbarr's enthusiasm erupts, but Seán sours as Graceland nears. This shift occurs after a cryptic scene midway through 
Grásta. Secondary figures of Cop and Waitress had been glimpsed early in the play, on television in Seán and Finbarr's New York City flat. Now, Seán witnesses what may or may not be a deadly shooting of the woman by the policeman. She, sobbing, had begun chanting a litany of Indian place names, and he, fed up, pulls out a pistol and murders her. Finbarr counters that Seán has viewed only aistíl (play-acting). Seán contends that he has witnessed an actual homicide; Finbarr insists that the conflict was enacted for -or broadcast live on-television.

Stopping at Nashville, slang-spouting Finbarr dons a cowboy hat. Seán doffs his hat. $\mathrm{He}$ rejects charade. Meditating upon Native American place names, Seán pits truth against Finbarr's pretense. Here, Ó Flatharta hints at the loss of an indigenous people's tongue. In this Irish-language play, substantial use of English -perhaps a fifth of the content-derives not only from the pair's American residence, but from macaronic patterns of their bilingual speech. For example, as Finbarr pens postcards, Ó Flatharta's directions remain in Irish even as their enactment whirs between the two characters' two native languages. He plants in his plays his roots: "Cé nach as Conamara mise ó dhúchas is fear Gaeltachta go smior anois mé. Tá an fhios agamsa céard is brí le dúchas. Tá mé ina measc anois sách fada le sibh a thuiscint. Mar a chéile muid anois. Aithníonn ciaróg ciaróg eile". (Ní Bhrolcháin 1989: 66-7) While he ends his explanation with a native proverb, Ó Flatharta does not fetishize Irish. Finbarr peddles Nashville in traffic that risks linguistic and cultural jet-lag once the card returns to its gullible Irish reader.

FINBARR: Ní chreidfidh siad go deo é nuair a fheichfidh siad na postcards seo. ( $A g$ scriobh go mall) 'Howdy Partner. I'm sitting in a bar in Nashville Tennessee' ...cé mead 'e' i Tennessee? ...caithfidh mé isteach ceann extra just in case... 'The weather is very hot. I have to go, Dolly Parton is looking for me. Wish you were here.' (Tógann sé cárta eile agus téann ag scriobh aris) Howdy... (Glanann sé amach an focal aris) No... ag mo mháthair atá mé dá chur seo... (Ag tosú arís) 'How are you. I am great. I am sitt... I am visiting Nashville, the home of country music. I have to go now, Dolly Parton is look... Dolly Parton sings here often. The weather is great. Wish you were here. (Le Seán) 'Bhfuil tú ag iarraidh cupla postcard?' (Ó Flatharta 1990: 43) ${ }^{2}$
The postcard writer betrays his predicament. Mimicking pre-fabricated vocabulary and barroom bravado, Finbarr sits blind to what Seán and spectators see. Finbarr stumbles when reporting the state's place name, goal of their pilgrimage. Seán searches within states' Indian meanings for primal identity. Seán loiters beside, waiting to speak.

Finbarr and Seán's code-switching between their two native tongues literally and figuratively presents their own transience. Seán blocks Finbarr's bluster. Seán gazed at crime. Finbarr shrugs. He gives no credence to what Seán sees, for all can be transmitted as aistill. They bicker at stations and stops. They seek a home turned a shrine, an icon buried. They leave a Gaeltacht where they never spoke its "pure" tongue at its linguistic reservation. They have never lived apart from America, but they are recent and illegal greenhorns. Both the homeland of Finbarr and Seán and the territory they now cross evoke emptiness. Behind evocative, ancient signifiers of places, earlier languages have been eradicated, adulterated, or abandoned.

Seán reifies alienation: "Bhí mé i mo shuí ansin ar an mbus is Meiriceá dul thar an fhuinneog de rite reaite, ar nós programme ar a television, d'fiafraigh mé díom fhéin cá raibh mé dul?" (Ó Flatharta 1990: 47) ${ }^{3}$ But the nation eludes him - the views could have been camera-framed, with he as detached spectator of locales with multisyllabic names now untranslatable. Fintan O'Toole summarizes this detachment within Ó Flatharta's drama: "Television and film, karaoke and computers, saturate his landscapes, unsettling identities and undermining language itself". (2003: 171) Indian knowledge dissolves. So do contemporary creeds. Grásta notices neither God nor Church. Seán searches no longer for Graceland but its root meaning. Finbarr comforts himself with visions of Elvis' home, memorialised as his grave. Seán spurns Finbarr, bitterly joking that he treats Memphis as if Fatima. Both pilgrims arrive at Graceland, searching for secular if not religious fulfillment.

After viewing glass reliquaries displaying Elvis' guitar, his rifles, and his Vegas Suit (worn for his televised "68 comeback special"), Seán and Finbarr ponder his calvary: tottering up Graceland's stairs to die on his toilet, a prisoner of a bloated body. Media resurrection of the King did not herald his 
triumphal ascension. Finbarr and Seán, disillusioned, agree that the United States is their predestined home. They have been indoctrinated with its fancies -first heard in their Irish cradles.

Seán resents tall tales of America's pioneers. He breaks the guitar case. While a busker strums "Lonesome Cowboy", Seán recounts boyhood games, when he pretended to be killed by Indians. Concluding, he, Finbarr, and the busker crouch around the grave of Elvis, three wiseguys listening for grace's descent.

In both Irish and English versions, Ó Flatharta kept the core plot of Seán and Finbarr's Graceland pilgrimage. The unpublished production script for Grace in America eliminates Cop, Waitress, and gravesite reliquaries. Grace introduces Con and Maggie, Seán's aunt and her husband, who live in Buffalo. Seán and Finbar ${ }^{4}$ detour there. This encounter comprises most of Grace's first act.

Under Kent Paul's direction, Grace was "completely revised" after its 1993 Cleveland run. (According to the director, however, no manuscripts are extant.) He staged it in Vermont in 2001. Its artistic director condensed Ó Flatharta's leitmotif: "he speaks about the play being a song of a play, that he likes a play to function like a song". (Charnoff 2001) In 1993, the author told of his "theory that all plays are closer to songs and ballads than they are to the novel, or even cinema". (Evett) This insight, repeated by Ó Flatharta in interviews and by Kent Paul to me, concentrates the focus of Grace for an international stage. ${ }^{5}$

Not unlike Finbarr, when Antoine Ó Flatharta reached the States in 1984, he spent three weeks cross-country on a Greyhound bus. He explains: "Growing up you are so aware of American music, American films, American everything. A whole America of the imagination is created in your head. I wanted to come to the real continent of America and see if those images tallied". (Evett 1993) With Grace, Ó Flatharta widens his panorama to include not only his generation, immersed in global culture, but that of his predecessors, postwar Cons and Maggies, who left a stagnant Conamara to help build a (perhaps) no less stereotypical 1950s America.

As in Grásta, the plight of illegal Irish in America spurs Grace. Its first lines of dialogue quote official offers of citizenship being granted Maggie in 1948 and Seán in 1993. Media retain prominence: Bing Crosby croons "Galway Bay"; the book "Famine Days" expresses Maggie's inherited pride. This volume's engraving will tease Seán and Finbar into stage Irishmen: "Sure it was that bad that the pigs in the parlour had tears runnin out of their eyes". (Ó Flatharta 1993: 32) When they regard a Famine depiction captioned "Clothes being given to the poor, County Clare 1849", Finbar mocks: "Not a Bennetton T-Shirt in sight". (32) This product placement captures a subtler assault of globalization; this clothing line striving at the time of the play's creation to vaunt its multicultural sensitivity on colorful posters not only with smiling models from all races but with professionally framed glossies of Third World poverty. Terry Eagleton observes: "A glossy colour supplement is culture, and so are the images of emaciated Africans it offers to our eye". (2003:48) The London Weekly Supplement's lithographs displayed across the Empire scenes drawn of the Famine. In the media-fueled capitalist culture that sells Elvis and Irish iconography both, globalization now pulls in the trivial and puffs it up as momentous. Piety pairs with poses. Grace is only the latest manifestation of selling destitution for distribution, exported for today's audience, more likely counterparts of Seán and Finbar than those of Con and Maggie.

Finbar relents, if momentarily: "Look at the places they had to live in - poor bastards". (32) Surprised by Maggie, the lads protest. They do not demean the past, but they weary of its presence. Seán and Finbar represent Americanized Irish. From birth, they can stay at home yet enjoy-if vicariously-Yankee crime and Southern charm. Con disdains such studied irony. He laments their loss of "that trust and innocence that made this country". (28) Finbar assuages Con; Seán resents deceit. When Con rages against "brave tomatothrowers of Galway" who protested Reagan's visit during the contra war, Seán snaps: "I just remember thinking at the time that Reagan was firin a lot more than tomatoes in Central America". (27-8) Con insists: "Our strongest weapon was our innocence". Seán mutters: "Tell that to the Indians". Maggie interrupts to play the cassette of Seán's dead greatgrandfather's voice. Séamus ${ }^{6}$ Molloy, thanks to progress that ships tomatoes back from 
America to Ireland and ammunition to Nicaragua, can intone cadences of -and forthe four characters' forebears.

Untranslated, Séamus' chant bonds them, although this intimacy slips after Maggie's phonetic repetition of Séamus' lyrics. She apparently has forgotten their meaning after nearly five decades in Buffalo. Ó Flatharta, avoiding translation of Séamus' lyrics, challenges listeners. If Grásta conveyed for Irish-fluent spectators a liminal community clinging to Gaelic even as Seán and Finbar ride across an anglophonic empire, then Grace offers a quartet of émigré Irish listening to the language Seán and Finbar still understand.

This aboriginal tug survives the leap from Grásta to Grace. When Con hears Seán banging a bodhrán that Seán took off the wall downstairs, he spits that the two lads act like "Indians". Seán enlivens what for Con and Maggie hung as an artifact bought at Shannon. But Maggie spurns Seán's lesson. For her, Ireland halts at a distance bridged only in her mind, not her actions. She resists returning to where no longer is home. Con also accepts his fate, to be buried in Buffalo. Talk of the grave overlaps with the struggle-- not only for Seán but for Maggie, once she maps the men's Memphis trip, to discover what American places mean in their Indian origins.

Seán struggles over "Susquehanna". Finbar shrugs: "Ya can say it any way ya want then. None a them around here t'correct ya". (30) Even Buffalo resonates as a mute ancestral void.. The near-extinction of a totemic animal hunted by whites reverberates as a warning for any community under Anglo-American hegemony. Seán tells Maggie that he dreamt of Ireland for the first time since emigrating. But what he envisioned was a sea of Bruce Springsteen fans at a Slane Castle concert, echoing on t-shirts what they heard the Boss shout: "Born in the USA!"

Ó Flatharta never loads these concerns too heavily upon Grace. Yet, they alert audiences attuned to global alterations. Fintan O'Toole diagnoses the author's tension "between a hankering after stability on the one hand and the placeless and amorphous feel of contemporary technological change on the other". (2003: 170-1) The review of its final Scotland staging ended: "the relentless humour is probably a vital antidote to the painful themes of emigration and exile, all too familiar in the Highlands". ("MO" 1994) Press cuttings record generally favourable reception to themes of linguistic and cultural loss. The 1994 tour's sponsorship, by Hydro Electric and Highlands and Islands Enterprise, imparts what its author and younger characters accept: modernisation of hinterlands, with an affirmation to allow its people to create yet control forces bringing and sustaining change.

Personal changes pull Finbar from Seán. Without telling Finbar, Seán gained a visa. This tension drives Act Two. The bus trip follows. Maggie asks for when the pair kneel at Graceland's grave: "Say a prayer for all the lost souls". (Ó Flatharta 1993: 54) This poignancy caps Act One's set-up of Indian spirits and Irish ghosts. In Con and Maggie's old Conamara schoolhouse, Seán had worked assembling cassette tapes until a grant expired and his employers fled. The now twiceabandoned locale may revive making fibreoptics. Technological mediums for media progress, even if Ireland tolerates amorphous control, now as in "Famine Days". Characters agree: that spot was haunted. Con and Maggie recall its sounds. They regress to Gaelic. The local plots with their stable descriptions: wet, dry, large, and small fields, emerge. Spousal articulation arouses dormant memories of place even more powerfully than Séamus Molloy's cassette, which Maggie could only parrot, shakily before Seán and Finbar's silent scrutiny.

Given Maggie's bodhrán, likewise, Seán revives concealed tones, easing anxiety by music. Finbar's guitar drives his Elvis homage as in Grásta. Finbar, discouraged by tawdry Graceland, chooses departure; Seán prefers the Cherokee progenitor of Elvis' drawl. Their pilgrimage ends with whispers, not Grásta's bangs. They sing "Danny Boy", one of the older Presley's favourite tunes, over his grave. Finbar leaves; Seán stays. He juxtaposes his jet departure with Maggie's boat leaving Cork city. Recalling Lancey and Owen's exchange in Act Three of Brian Friel's Translations ("Swinefort/ Lis na Muc; Burnfoot/ Bun na Abhann; Drumduff/ Drom Duibh;" [1984: 439]), Maggie and Seán evoke native American and Irish placenames: "Garrai na gCaorach/ Catahoula; An Garrai Ban/ Tacoma; An Garrai Beag/ Tallahassee/ An Garrai mor......." (Ó Flatharta 1993: 80b)

The play ends as Seán stands alone, beating Maggie's bodhrán. He adds one site, the birthplace of Elvis: "Tupelo". Ó Flatharta's 
stage direction is Grace's final expression. "And the word is made flesh". This refers to the Scottish tour's staging. The Statue of Liberty, present on stage although never in the script, lights up a figure of Elvis within. (Pope 1994) Easter imagery, submerged within Grace where it had emerged in Grásta, reveals the glowing revenant that lights the New World's portal as it had the oul' sod's schoolhouse.

Reviewers on and interviewers of Grace fail to sight the ghost flitting about American and Scottish coverage of the English-language version. Neither author nor critics reveal Gaelic paternity engendering Grace. Ó Flatharta defends Irish. Journalists claim his pre-eminence among Irish-language playwrights. But this play's creator and mediators share "the great silence" Seán de Fréine defined as shock muting Ireland's old vernacular after the Famine. Perhaps Maggie's uncomprehending imitation is all that most Irish now expect from Séamus Molloy's reverie.

Kent Paul responded to my query about changes between Grásta and Grace: "I never knew of a previous version in Irish". This director in 2001 having worked with their author, his admission puzzles me. Whatever the reason for the omission of the Irish engenderer from its English offspring, the two are not entirely severed. Comparing both plays, one speech survives intact. Seán conjures the funeral and internment of Séamus. In Grásta, this vignette preceded the Finbarr's smash-up of rifle and guitar cases. In Grace, this recollection shades into the graveside offerings by the living to the dead. Seán and Finbar replace violence with veneration. They return to Irish language and music, to pray for the poor souls, to fulfill Maggie's request.

Both Indian names and Irish locales summon up past lives and cultures that recur today. Unlike so many native American vernaculars, the Irish into which the writer and characters of Grace and Grásta were born may still speak to audiences able to harmonize both plays' dramatic, musical, and cultural energies. Examining prospects for the survival of Irish itself, however, complicates reception and transmission not only of these two versions of Seán and Finbar's Graceland pilgrimage. It also reveals insights by Ó Flatharta into the fate of Irish within a globalized, anglicized, and Americanized context. This analysis, in turn, heightens the post-colonial relevance of these plays.

While critics have very rarely examined Ó Flatharta's drama directly, application from post-colonial and nationalist academic theories enriches an understanding of his bilingual productions. I will apply terms from Seamus Deane's introduction to three Field Day pamphlets, to expose the fractured construction of Ó Flatharta's plays. Deane examines how mapping and naming force reconsideration of how territorial shifts compare with linguistic shocks. Deane prefaces his remarks to three critics who continue Field Day's mission to reclaim a viable cultural nationalism. This campaign, which began with the Derry group's 1981 sponsorship of Brian Friel's Translations, continues in the 1988 Field Day pamphlet from Edward Said. His concept of the "cartographic impulse" supports my reading of Ó Flatharta's dramatic and linguistic complications, as the playwright negotiates through Irish with an English that dominates not only his characters but (perhaps surprisingly) his own subsequent authorship. Declan Kiberd's examination of the interdependence of these two languages focuses my look at Ó Flatharta's own elegiac reaction to those who would scour his native Irish tongue. Kiberd's notion of Ireland as its own "open air museum," furthermore, bolsters Ó Flatharta's own revulsion at what his Gaeltacht has become, and his rejection of those who wish to keep it as a theme-park exhibiting rare species of pure Irish speakers. Sociolinguistic theories of creolization support Ó Flatharta's own decisions, dramatized by those in Grace and Grasta, to accept the media power of America over the parochial exhibition that has been constructed out of their Conamara Gaeltacht.

Seamus Deane observes that the "naming or renaming of a place, the naming or renaming of a race, a region, a person, is, like all acts of primordial nomination, an act of possession." After a litany of various names by which Ireland is labeled, he cautions that their vigor masks weakness. Ultimately no name suffices; "instead of possession, we have sectarian appropriation." (1990: 18) Deane's "primordial nomination"-the gift given Adam by God in Eden-finds its echo in the fallen realm traversed by Seán and Finbar. Seán has resisted the "sectarian appropriation" by restoring the "primordial" to the anglicized placenames as best as he can. On the bus, he 
studies the map and struggles to match what he has read to the actual terrain he now watches from a Greyhound window. The distance is not diminished -he still remains a spectator removed from the indigenous voices. But he listens to their faint resonance, in the only testimony extant. By summoning up the original place names, he strives to overcome what his own media immersion and Elvis fixation have distorted. He has nearly forgotten the roots of the country that Elvis knew and that America commemorates, although in a degraded fashion. While Ó Flatharta never explicitly grants Seán any lines in Grace that attest to his wish to link the Indian to the Irish languages, the playwright, by bringing back Maggie on to the stage at the end of the play, joins these two appropriations that admittedly speak in "sectarian" but nonetheless more "primordial" tongues that named the places before the coming of English. Maggie is summoned by the playwright from the past, and she then brings back the play's backstory, nearly forgotten in its communal, Gaelicized topography after her four decades in Buffalo. Seán joins Maggie in naming the locations that they have seen and those about which they only have heard, in their original Indian and Irish names. Maggie had earlier begun to trace on her own American map the route taken by the two young men. She joins their quest vicariously.

Seán and Maggie revive dormant powers through shared language. Maggie had nearly erased her command of Irish; Seán had learned on his bus trip, as his quest ends at Graceland's grave, how much he had learned the ancestral nomenclature that represented so many of its states and cities and features. They stand for what Edward Said, in his Field Day pamphlet, calls the cartographic impulse. A feature of the language of "anti-imperialist resistance", this succeeds the natural world and the political mapping that has replaced the original names with those of the colonizer. This recovery, as Seán and Maggie signify, follows Said's rejection of any romantic return to the pristine or the pre-historical. The Gaeltacht subsides beneath the weight of Béarla. The Indians cannot be resurrected. Still, the attention that Seán and Maggie pay to the original names reclaims the territory that the natives had lost, by symbolically voicing, in Said's phrase, "an almost magically inspired, quasi-alchemical redevelopment of the native language". (1990:
79) From a "poetically projected base", Said explains, fresh territory emerges, full of "assertions, recoveries, and identifications". Finbar, Maggie, and Seán share this cartographic impulse. Even Con overcomes the negative association that his name suggests, for he and Maggie together have revived by their combined memory the communal placenames of their birthplace. These summon up respect for what throughout their American residence has been relegated to the quaint and the nostalgic, nailed to the wall like the bodhrán from Shannon airport. Seán takes down the artifact and makes it an instrument through which the Conamara music returns. Maggie and Con find that they remember more Irish than they might have supposed. Finbar and Seán's graveside music brings back laments but also life in the midst of death, as they give Elvis his impromptu American wake.

Said designates the reclamation of a more authentic identity by the colonized as a search for "a more congenial national origin than that provided by colonial history".(79) Finbar and Seán do not erase Yankee damage; the tomatoes thrown in Galway remind them of the hubris of American power, the excess after the energy that Elvis epitomized. Con's role remains a difficult one for an audience to find sympathy with, but his own belligerence earlier in the play gives way to tenderness once he is alone with Maggie. The ghosts can return, and they carry to their conjurers no longer fear but reverie. Throughout both versions of Seán and Finbar's pilgrimage, Ó Flatharta sidesteps jingoism and deflates celebrity. In Grace, he allows by the addition of Con and Maggie a more nuanced portrayal of the post-colonial Irish emigrant experience than the strictures of Grásta could hold. The ambiguity of the shooting of the Waitress as she spouts Indian placenames, and the limitation of the cartoonish tantrum of Finbar near the play's climax compressed an overly ambitious array of images and suggestions that the dramatic framework could not easily support. For Grace, Ó Flatharta clears more room for his characters to come to terms with their shortcomings. Both couples learn slowly what Ireland could offer and cannot provide. America, for all four of these Conamara Irish, becomes their home, despite all of its colonial depredations, for such a history for the Irish cannot ever be eluded. ${ }^{8}$ The only power that the emigrants possess is to select their place. 
America remains tawdry, but beneath its gaudy surface, beauty and sincerity still beckon, as Maggie seeks to find on her map.

O Flatharta keeps a steady control over his depiction of contemporary America. He rejects the facile cynicism often indulged in by critics of American hegemony. As his interview comments demonstrate, he balances criticism with celebration of what the New World has given to the Irish who have visited and who have stayed. He respects native heritage and immigrant enrichment. These may uneasily mix, but as Elvis' Cherokee origins and Grace's last word "Tupelo" remind the audience, although perhaps too subtly, the United States mingles many origins. At play's close, both Finbar and Seán have chosen as their home. Like Maggie and Con, they cannot forget their Irish identity; nor can they reject their American impulses. The end of Grace captures this crooked journey back to finding an Irish identity on American soil, blessed by Liberty's light.

The power released by placenames that Deane and Said examine also occurs in Ó Flatharta's last Irish-language play to date, $A n$ Solas Dearg. As in Grásta, Irish dominates but English enters nearly every conversation; one character rarely speaks in Irish except in a few intimate family moments. The attitudes of natives to those from outside the Gaeltacht who would wish to save its inhabitants from their abandonment of Irish as it "should" be spoken emerge in representative recitals by two contrasting characters. Danny works for Gaelic television but, unhappy with dubbing cartoons into Irish, chooses to leave Conamara after Disney offers him a job in California. Justifying his departure to a co-worker, he explains the allure of American media and the myths it peddles and which he too wants to create and sell.

DANNY: Níl mé ag iarraidh cois a bheith sa dá aít agam. Tá mé ag iarraidh mo choise in aít amháin. Clean break. Anyway, Jesus, céard tá ort? Tá muid ag caint faoi LA! Hollywood! Tá sé 'nós dul go Mecca no rúd éicint. An fear seo as Disney, bhí sé tar éis teacht ó film shoot i Monument Valley. Dá gcloisfeá na háiteacha a bhí sé ag liostáil amach, Nóirín! Malibu, Santa Monica, Long Beach, Burbank, Santa Barbara, San Diego, San Bernadino. (Stad) Universal city. (Stad) Universal city. (Ó Flatharta 1998: 59) ${ }^{9}$

Danny's enthusiastic leavetaking contends against impassioned praise by Seoirse, a fervent Gaeilgeoir, an "incomer" who has moved to Conamara and who works with Danny. He tells his wife, a native of the area, why he can never now live anywhere else.

SEOIRSE: ... An solas dearg sin nach bhfuil le fáil aon aít eile sa tír. Bearna, Carna, Casla, An Cheathrú Rua. Leitir Móir, Leitir Mealláin, Beal an Daingin. Bhí ceol agus fírinne sna hainmeacha. $(61)^{10}$

In the music of the Gaelic placenames, Seoirse finds not only poetry but truth. Danny, lured by California's richer mixture of Spanish, Indian, and English nomenclature, hears in their sounds a similarly enchanting siren song. Both men, opposed in their attitudes towards Conamara, will bitterly argue. The native will depart while the "blowin" will stay, enamored by the "red light" of the play's title. Yet both represent how the alchemical potential of language unlocks within contemporary Irishmen the power of the media and the power of the soil, and how these can compete with one another, within the same locale.

Such tension, as Seán and Finbar grapple with before they too succumb to the overwhelming appeal of multicultural and multilingual America, seems to win over those accustomed only to the shocks on the smaller battleground between anglicized and gaelicized proponents from Ó Flatharta's home turf. Whereas Friel's Translations uses the battle over the renaming of Irish terrain to represent a larger colonial appropriation through mapping, the "cartographical impulse" Said locates escapes the trap of a solely bilingual opposition. All the world's languages can be added to the rich mix of creoles and pidgins and blends that follow colonialism in its ebbs and flows.

In Ó Flatharta's Elvis plays as well as $A n$ Solas Dearg, nature itself will come to lure in its viewers made listeners. Nature can only speak through words in the limits of the stage and dramatic representation. The playwright relies upon what must remain unseen within the theatre to unleash the total potential of the power that his litanies possess. Their alchemical potential bursts through by releasing the placenames and allowing their aura to create the air of longing that transcends mere locations, and that illustrates that which it comes to signify and embody: the media's pull to draw in the viewer and the listener. Seán and 
Finbar, drawn to Graceland by the promise inherent in its name, decide both to never leave. They stay in America, both content at last. They follow Con and Maggie's example. They know that the media conjures up the names they consume, but they are content with such a repast. "Universal City" is a studiotheme park-shopping mall that recreates in miniature the front facades of tourist attractions from the greater Los Angeles sprawl. Danny may not yet know about this reduction of the real city into the manufactured similacrum, but the mundane reality will not dazzle more than the appeal of a cosmic reach that the media's broadcasts convey. He knows that Disney dumbs down the myths of many nations, but Danny decides to embrace rather than resist such "starmaking machinery". Like Danny, Seán and Finbar choose to accept America even as they confront Nashville's tawdriness and Buffalo's conformity. Its charms dazzle even when their props are revealed. The magician's act still succeeds.

At first, Ó Flatharta's retreat from writing in Irish, for since An Solas Dearg he has not published any plays in the language, perplexed me. His reason may reveal itself by its absence, as when Kent Paul told me he knew of no previous version of Grace in Irish. Apparently, the author of Grásta did not reveal that his Irish drama preceded -or engendered- the English version that he had written and that Paul had produced in 2001. The author's decision to revise Grásta into Grace, given his remarks in an interview from earlier in his career, could be considered a logical extension of his attitude towards the survival of one of his two native languages.

Ní féidir le hionad lárnach a dtuaraimí ar theanga bheo a bhrú ar na daoine a labhrann a teanga sin. Murar féidir leis nGaeilge fás agus forbairt go nádúrtha ina timpeallacht fhéin- tá sé chomh maith cúl a thabhairt uirthi, ligint di bás a fháil go nádúrtha, le dínit agus tórramh ceart a chur ar fáil. (Ni Bhrolcain 1989: 667) ${ }^{11}$

Máirín Nic Eoin reads his plays as demonstrating "léargais na teangeolaíochta criólaí". (2005: 355) This "view of a creole linguistics" emerges from Ó Flatharta's attitude towards its impending demise. His unsentimental attitude towards Irish and his refusal to sentimentalize the decisions of his characters away from Irish and for American English, as Grace dramatizes, only confirm the author's determination to reject romantic "professional Gaeilgoirí". Ó Flatharta in his plays depicts accurately the idealization of the Gaeltacht by students or "blow-ins", but he never grants these earnest characters the power to see their dream of an Irish Ireland come true. He never kowtows to what he regards as meddling agents from Dublin or snobbish teachers who try to purify his community's creolized but honest version of contemporary Irish.

Creoles emerge when a pidgin language develops into a mother tongue spoken by its children. (Edwards 1994: 43). Technically, "na teangeolaíochta criólaí" does not precisely define the mixed Irish-English spoken by Seán and Finbar, but it does match what one sociolinguist finds as "the creole reason" why imperial languages outlast the empire that brought the language. Nicholas Ostler observes of a newly dominant tongue: "it remains the language of the people who dissolve the empire". (2005: 444) It may evolve, as with present-day Irish, into an unstable and combative compound. Certainly this dissolution of traditional Irish, that held off for so long the advances of English, troubles many observers. Despite -or because of- the government's clumsy attempts at its revival over the past century, anglicization and AngloAmerican media, as well as a European contingent of holiday homeowners and retirees, now erodes the last redoubts of a supposedly pristine Gaelic. In the effort to preserve a "fior-Gaeltacht", to protect its purity, such state intervention often angers speakers who may be castigated for their impure loanwords and grammatical interference. This action by the state or a cultural body hastens a language's demise, as its users shrink from using it in public and avoid criticism by only speaking their tainted blend at home. This in turn weakens the community bonds that the language sustained, and only accelerates pressures that crush the language. (Coulmas 2004: 167)

As Ó Flatharta's interview in Irish admits, the author would rather see his Irish language die off in peace, "go nádúrtha"-naturally and with "dínit," dignity. With Ó Flatharta's unsparing ear, Grásta's code-switching accurately records Irish as it is spoken in his native district. Whether it should be spoken as such becomes moot. Last gasp or the rise of an alternative third hybrid Hibernian dialect: this 
cannot be demarcated by its present speakers. Seán and Finbar simply talk as they have always heard Irish spoken "go nádúrtha" in their Americanized Gaeltacht. Shaky intimacy, as shown in the uncertain register of the codeswitching exchange quoted at the Nashville souvenir shop, replaces linguistic monogamy or ancestral fidelity. There, Seán's disgust at the peddling of the Indian's fate and the cowboy's victory as a cheap souvenir hat contends against Finbarr's delight at such commodification of Manifest Destiny. This shift from real to manufactured, as imperialism sells what it has eliminated, parallels the native Irish experience, not only in goods but in the ability to even express such a cultural eradication. The fragmented Irish spoken, as Ó Flatharta reminds us in his comments, captures a complicated decision that belies easy separation of victim and conqueror, blow-in from indigenous inhabitant. The Irish, Declan Kiberd remarks, "were the only European people who taught themselves English in their own country, even before their exiles reached England or the New World". (2005: 284) While not always a free choice, this decision by millions of their fellow islanders to replace Irish with English, over the centuries, now appears to be made by many among its last Gaelic speakers, as the prospects of Irish as a community language decline in the Gaeltachtaí themselves.

One linguist recently notes: "Given the passive nature of the support of Irish society in general for the Irish language it was inevitable that the symbolic capital of the Irish language as the national language would be difficult to translate into other forms of capital, other than that an influential player intervenes in the marketplace". (Mac Giolla Chríost 2005: 132; see Murphy 2005) Here, Pierre Bourdieu's theory of capital transfer proves relevant. (1986: 241-58) He explains how the habitus the collective consciousness- can be accumulated through capital accrued from power attained through a community's investment in various social fields. Individuals share in this capital by what becomes an "inherited disposition" towards its worth. People can express their particular appreciation for their culture's shared investment, moreover, by varying methods. These can be spiritual, symbolic, or strategic. With time, as priorities change, so can the manner in which the habitus is perpetuated. (Inglis 2005: 62;
Mac Giolla Chríost 2005: 10-17).

For native Irish speakers today, their entry into English-dominant public discourse moves their Celtic habitus. As the Gaeltacht Irish themselves assert their right to withdraw accumulated cultural capital, they devalue their now diminished and domesticized language. By choice, as Ó Flatharta and his characters express in their refusal to fossilize a changing and creolizing Irish language, they now invest their long-acquired capital into producing more tangible commodities. Furthermore, the death of Irish hastens its commemoration through relics. Traffic in bodhráns bought by -or forCon and Maggie may support a Shannon vendor but it cannot sustain Conamara's folk. They seek employment and choose emigration away from an boom-bust economy dependent upon the collusion of foreign capitalists with Irish bureaucrats. Sightseers may gawk, but neither the author nor his characters will keep playing the role of contemporary actors posing as historical figures, their only employment option being that merely expanding the stage's margins from the workplace into their own homes and villages, as if a Bunratty Castle folk museum exhibition.

Declan Kiberd expounds on "spiritual tourism." This making of Ireland into "a gigantic open-air museum" full of heritage centers, "in which remnants of the past can be examined by a process of instant archeology," (1991: 119) complicates Seán and Finbar's own reactions to Graceland, with its displayed relics and its patronized grave. Bitterness and envy contend against awe and wonder. Their childhood fantasies of arriving in Memphis now realized, they too have turned tourists in another theme-park, mirroring their own native region's transformation into a Celtic cultural reservation. They choose to leave Conamara rather than submit to this latest spectacle of a post-colonial but determinedly anglicized culture. They may, however, have to join it anyway and submit to its Americanized version, sold via Bennetton. Seán and Finbar's survival can no longer be assured unless they, like the "poor bastards" who fled the Famine, leave for a new land. The failure of the ghosthaunted school turned abandoned factory, once its Gaeltacht industry grant ended, reminds the audience of Grace how fickle the capitalist market can be for Celtic tigers.

For the characters of Grace, the decision to seek gain rather than struggle to live within a 
picturesque but decaying backwater becomes shared between the post-war and the nearmillennium generations. Seán and Finbar have never known Irish without English. Peter Trudgill explains that in an English-dominant context, the mixing of the minority language with English "is presumably subconscious, and has the effect of making the conversation, among other things, more intimate and confidential". (2000: 106)

Conventionally, Irish sprinkled within an English-language play -while it reminds many of the country kitchen stagings by Ernest Blythe's Gaelicized mid-20th century Abbey Theatre- stands as shorthand for the entry of emotion from Gaelic into Hiberno-English. But now, true to Said's prediction, the "native language" undergoes transformation into previously unsuspected shapes. Polyvocalism thrives when nonstandard English emerges from modernism into the flux of our current, unstable postcolonial condition. (Crystal 2004: 487) Said's confidence in the "cartographic impulse" and its concomitant ability to shapeshift familiar surroundings through linguistic magic all the more doubles when neither English nor Irish, as the two versions of the Graceland quest show, can claim ownership of the story of Seán and Finbar. ${ }^{12}$ With the media's invasion welcomed by Finbar and accepted by Seán, their control of Elvis' posthumous power increases rather than diminishes with time; not only Finbarr but also Seán impersonates the King, as their idol's celebrity resists the sordid reality of his demise. The two Irishmen reject the grave for the dream of America that Elvis personifies, and ironically repeat the stock violence that destroyed the Indians and impelled the cowboys. Such spite impels Seán and Finbarr to shatter the displays. Tension escalates as Finbarr threatens to shoot Seán. This explosive aggression near the end of Grásta eases, with dramatic revision and therefore textual elimination, to their acceptance that not fate but action will bring about the future dream-vision, the aisling in Liberty's appearance that calms Maggie as well as Seán and Finbar in the last moments of Grace.

As the play closes, it ends with Maggie and Seán's exchange in two native tongues, those of the first Americans and the Conamara Irish. But the rest of the play is in English. Irish may remain, but as ghostly as the Indian names which haunt the landscape. Whether the characters in the two plays who commemorate these places through the medium of English, near the cusp of the $21^{\text {st }}$ century, can preserve threatened vernaculars or merely repeat their signifiers, remains doubtful. While Maggie still recalls and Seán still speaks Irish, if left in America, English will overwhelm their command of Irish as inevitably as it has nearly extinguished most Native American speakers. ${ }^{13}$ Can an Irish traditional lifestyle continue, or will it be only memorialized or trivialized, as is the case with the media's Indian? Ó Flatharta keeps an open mind. From the suggestions in his plays, he neither condemns nor celebrates his culture: he dramatizes its conflicts. Terry Eagleton's insight applies to Ó Flatharta's detached vantage point: "Being inside a culture is not like being inside a prison-house. It is more like being inside a language. Languages open to the world from the inside. To be inside a language is to be pitched into the world, not to be quarantined from it". (2003: 62) By refusing to idolize his native Irish, and by accepting his native English, Ó Flatharta enacts, as do his characters, his freedom in a diasporic world to choose his destiny.

Translation attempts to bridge such gaps in cultures as Native American from AngloAmerican, or Irish Gaelic from HibernoEnglish. Yet, comparing the two plays, almost nothing is directly repeated. The first play does not match the second. Grásta and Grace share only Graceland and two main characters. While they both end with Seán and Finbar's decision to remain in America, the latter presents ambitiously what the former suggests tentatively. The bold but constrained and rather inarticulate vocabulary of the two young men through which Ó Flatharta presents polyvocal possibilities as Irish blended with English in Grásta gives way, similarly, to a more controlled characterization of the two men in Grace. Seán gains in English a confidence he lacked in Irish. Finbarr lost control at the end of Grásta; he gains empathy in Grace. Con and Maggie offer characters against which the two men can contend and compare. The journey, not only to Graceland but in Grace via Buffalo, expands the Native American aura that, filtered through all four characters' Conamara memories, grows richer and more nuanced.

The monolingual majority of the speeches in Grásta narrowed its reception to an Irish audience, and a limited one in fleuncy and 
dedication to support Irish-language theatre at that. The passivity of most Irish citizens towards their first "official" language enervates much of the possible audience for Irish-language drama. As a truly minority literature, the alchemical potential in Irish exists, but this energy still remains dormant over most of the island. With few prospects presumably open for Irish-language drama, Ó Flatharta turns towards English, and takes his show to America, far beyond the Gaelic fringe that received his 1994 Scotland tour of Grásta. Acclaimed as a leader of Irish-language drama at the start of the $1990 \mathrm{~s}$, well before the decade's close he will produce no more theatre in the language in which he began his career. The tension underlying the loss of Irish to English within his community's speech widens as Ó Flatharta retreats from publishing in one of his native tongues.

For the characters and the author of these two plays, code-switching complicates linguistic or critical categorization. What is Ó Flatharta's "native language"? $\mathrm{He}$ and his dramatic speakers refuse to be labelled by only one identity. While the characters in his plays do not surrender their Irish-language allegiance, they subsume it to the more tangible, and lucrative, rewards that English has brought in its mercantile energy. In the post-colonial and globalized world, where pidgins and creoles follow the breakdown of political borders and communal barriers as English continues its expansion, Seán and Finbar, like Con and Maggie, continue this inevitable anglicization. The last lines of Grace conjure up Native American and Irish Gaelic places. But these both are those spoken more as commemoration than in perpetuation of their indigenous identifiers. The places of the past keep their old names, but future inhabitants will speak of these places in a new tongue. For all four Irish characters in Grace, as well as the two in Grásta, whether they stay in Conamara or leave for America, English relentlessly triumphs.

The shaping of Grásta into Grace also proves the centrifugal pull exerted by English in this post-colonial, media-savvy culture. Ó Flatharta never revealed to the Vermont Theatre's director of Grace the existence of its Gaelicized predecessor; this reticence to return to Irish remains consistent with O Flatharta's subsequent career. While he never had written solely in Irish, his recent work has moved decisively away from the language. He no longer lives in his birthplace of Leitir Mealláin off the Conamara coast. Dublin-based since the early 1990s, he now writes in English. Published a year after An Solas Dearg, his children's book The Prairie Train celebrates a rail journey further west into the American plains, continuing another quest that stretches the horizons pursued by his Buffalo, Hollywood, New York, and Memphis-bound emigrants even further into the heartland of America. Conor, emigrating with his parents and travelling by steam train across the continent from Chicago to San Francisco, loses the toy boat his grandfather had made him, Conor's symbolic link with his seaside Irish birthplace. In a dream, the boy finds comfort in his grandfather's assurance: "It's the same moon that's shining on all of us. Makes no difference if you're in Connemara or San Francisco". (O Flatharta 1999: 26) Conor learns the promise held by America, much as Seán and Finbar had: "There's bigger boats waiting for you", he is told.

Hurry and the Monarch tells of a tortoise who meets, in Wichita Falls, Texas, a monarch butterfly en route from Canada to Mexico. Again, the particular surrenders to the universal. The narrow vision of those rooted in one place opens into the vast panorama enjoyed by the traveler. Ó Flatharta's second children's story spans the whole North American expanse, as the monarch's journey takes her even farther than Conor, let alone Seán or Finbar. Concluding their adventure, the two emigrant Irishmen of Ó Flatharta's Elvis plays decide, like immigrant Conor and the monarch migrant, to accept the possibilities held by America for its newest arrivals. Despite their natural and linguistic diversity, they all choose to listen to America's message, spoken in English, as one that transcends the insularity of Irish, however native or cherished, for the potential energy and childlike wonder of a global language that wins allegiance and affection.

\section{Notes}

1. "Since I'm from Conamara myself there's the instinct of a Gaeltacht man now in my marrow. I know for myself what it means by nature. Now I've long been crammed with this insight. We're all together now. One beetle knows another". (My translation) Quoted in Nic Eoin (2005: 202). 
2. Irish phrases - my translation: “They'll never believe it when they see these postcards (Writing slowly -How many 'e's in Tennessee?...I'll throw in an extra one...-(He picks up another card and goes writing again) (He erases the word again) No...my mother's there if this gets to her...(Starting over) - (To Seán) You're asking for a couple of postcards?"

3. "For me sitting there on the bus there's America going by the window stretching out running by, like a television program--I ask myself: where am I going?" (My translation)

4. In Grace, Finbar is written with only one " $r$ ".

5. Early 1990s New York City staged readings of Grace, see Paul 2004; Thomas 2004; Whyte 2004. 1992 at The Red Lion, London, see Devine 2004. 1993 Cleveland Play House version and interview with Ó Flatharta, see Evett 1993. 1994 at Traverse Theatre, Edinburgh, see Coull 2004. 1994 Highlands and Isles Scottish tour, see Black 1994; Mathieson 1994; Pope 1994. 2001at Lost Nation Theatre, Vermont, see Lang 2004; Paul 2004; Thomas 2004. I quote Grace's manuscript in the Traverse version provided by Coull and the Vermont version provided by Thomas. Minor pagination variation or excised portions do not effect passages cited for this essay.

6. In Grace, Johnny is re-named Séamus. I have added accents to Seán and Séamus; they are absent from the typewritten versions of 1993 scripts that I have consulted. I assume that these were revised by Ó Flatharta. Vermont (provided by Thomas) and Edinburgh (provided by Coull) copies share identically handwritten emendations and deletions. In Grásta, accents appear for Irish names.

7. Compare Colm Breathnach's 1992 poem, “Trén bhfearann breac", analysed in Nic Eoin (2004: 271-3). The study of this poem and its titular itinerary ["Through the speckled land"] where "tá dhá ainm ar gach aon bhaile ann" ["every town there has two names"], expanded in Nic Eoin's 2005 book applying contemporary theory to semi- and post-colonial Gaelic literature, gives her incisive critique written in Irish not only its title but its exemplary expression of "the intercultural tendency and uneasy in-between-ness which is the outcome of an unequal and destructive cultural encounter”. (2004: 272)

8. Joseph O'Connor recalls his boyhood summers spent away from Dublin "to the edge of Connemara", An Spidéal on the Gaeltacht frontier of Cois Fharraige. His encounters there with vacationing Americans sparked his longing to explore the U.S. In his book he visits towns named "Dublin" scattered over America, searching for why they were named after his hometown. From an old woman who had never been to Dublin but had spent years in New York, the boy O'Connor is told: "I would have to go to America myself when I grew up, she said, because Ireland was a very small place to live". He explains: "In those few moments, the balance of Ireland tilted in my mind. I stopped seeing Ireland as a place which revolved around Dublin, and I began to see it as a place which revolved around America. The map of the world shifted, too, in my childish imagination. No longer just off the coast of Britain, Ireland was now just off the coast of Massachusetts". Home from his holidays, he "hung an enormous map of America on my bedroom wall". Like Seán, young Joseph finds himself moved by the "cartographic impulse" Said describes. His later travels make real his youthful dreams. O'Connor looked at the map when he woke up, "trying to learn how to pronounce the strange and glamorous names of American cities. How did you say 'Albuquerque'? What about 'Roanoke', 'Terre Haute', 'Des Moines', Baton Rouge'?” He finds nowhere else comparable to "this fabulous and distant land", as "[m]y own bedroom became an America to me. My own private America”. (1996: 2; 8-9)

9. 'I can't wait to set foot in that place. I'm waiting to set my feet down in that very place. . . Jesus, what about you? We're talking about LA. . . . It's like going off to Mecca or something. This man from Disney, he's come back after a film shoot in Monument Valley. . . . If you could hear the places that I'm rattling off, Nóirín. . . . [Readers of Estudios Irlandeses may note an error in this local litany. Unwittingly, perhaps Danny and Ó Flatharta recite L.A. linguistic labels better than they may both realize; local mispronunciation by native Angelenos habitually elides the nearby city of San Bernardino into "Bernadino", as misspelled here. Placenames continue to be pressed under the pressure of two colliding cultures and languages, in Spanish as well as Irish when it comes to the competing crush of English.]

10. "You can't get the red light here any other place in the country. . . There's music and truth in the names".

11. "It's impossible to nail down any basic idea that the living language is crushed by the people who speak that language. It might be better for the growth and development of Irish for it to naturally surround itself -it'd bring it to a good end, allow it to arrive at a natural death, to give it dignity and a proper wake".

12. (As I type this line, my son interrupts to inform me that Jonathan Rhys-Meyers, an Irish actor with a partially Welsh surname, has won a 2005 Golden Globe for his starring role in a television series as Elvisanother indication of the media's reach that extends Seamus Deane's remapping. Rhys Meyers thanked the audience for his award -in Irish.)

13. James McCloskey asserts that "there is nothing special about Irish. It is a language like any other, neither more or less worthy of support than Yupik, Inuit, Chamorro or Maori". His book explores parallels between the fate of indigenous tongues worldwide and "this froth of linguistic experimentation and creativity" in creolizing, pidgin, and urban forms of Irish that accompany the established three Gaeltacht vernaculars. $(2001: 42,48)$ 


\section{Works Cited}

Black, Ian. 1994. "Searching for a State of Grace". The Herald [Glasgow] 22 Apr.: 10.

Bourdieu, Pierre. 1986. "Forms of Capital". In Handbook of Theory and Research for the Sociology of Education. Ed. John Richardson. Westport, CT: Greenwood. 241-58.

Charnoff, Neal. 2001. "VPR Backstage". With Eileen Brennan, Kent Paul, Kim Bent. VPR_News. 19 July. Vermont Public Radio. Transcript. 8 Nov. 2004.

$<\mathrm{http}: / /$ www.vpr.net/vt_news/stories/backstage/backstage3.shtml>

Coulmas, Florian. 2004. Sociolinguistics: The study of speakers' choices. Cambridge: Cambridge UP.

Coull, Neil. 2004. Letter to the author. 9 Dec.

Crystal, David. 2004. The Stories of English. Woodstock, NY: Overlook.

Deane, Seamus. 1990. "Introduction". Nationalism, Colonialism, and Literature. Minneapolis: U of Minnesota P. 3-19.

Devine, Helen. 2004. E-mail to the author. 16 Dec.

Eagleton, Terry. 2003. After Theory. New York: Basic Books.

Edwards, John. 1994. Multilingualism. London: Routledge.

Evett, Marianne. 1993. "Irish Playwright Likens Elvis Shrine to Religious Experience". Cleveland Plain Dealer 31 Oct., Arts \& Living: 10. ProQuest. 3 Dec. 2004.

Friel, Brian. 1984 (1981). Translations. Selected Plays of Brian Friel. London: Faber. 377-451.

Inglis, Tom. 2005. "Religion, identity, state and society". In The Cambridge Companion to Modern Irish Culture. Eds. Joe Cleary and Claire Connolly. Cambridge: Cambridge UP. 59-77.

Kiberd, Declan. 1991. "The flowering tree: modern poetry in Irish”. An Crann faoi Bhláth: The Flowering TreeContemporary Irish Poetry with Verse Translations. Eds. Gabriel Fitzmaurice and Declan Kiberd. Dublin: Wolfhound. xi-xlii. Rpt. in The Irish Writer and the World. Cambridge: Cambridge UP, 2005. 105-26.

2005 (2003). "The Celtic Tiger: a cultural history". Parnell Fellowship Lecture, Cambridge University. Rpt. in Kiberd, Irish Writer. 269-88.

Lang, Susan. 2004. E-mail to the author. 7 Dec.

Mac Giolla Chríost, Diarmait. 2005. The Irish Language in Ireland: From Goidel to globalisation. London: Routledge.

Mathieson, Kenny. 1994. "Long and Winding Road to Find an Identity". The Scotsman [Edinburgh] 23 Apr. (cutting: no pag. indicated)

McCloskey, James. 2001. Voices Silenced: Has Irish a Future? Guthanna in Éag: An mairfidh an Ghaeilge beo? Dublin/Baile Átha Cliath: Cois Life.

"MO". 1994. "American Dreamers Wake Up". Rev. of Grace in America. Dir. Philip Howard. Ballachulish Village Hall. Highland News Group. 18 June. (cutting: no pag. indicated)

Murphy, John L. 2005. Rev. of The Irish Language in Ireland: From Goidel to globalisation by Diarmait Mac Giolla Chríost. LinguistList (22 Nov.). http://linguistlist.org/issues/16/16-3392.html\#1

Ní Bhrolcháin, Muireann. 1989. "Antoine Ó Flatharta mar Dhrámadóir Gaeltachta”. Léachtai Cholm Cille 19: 66-7.

Nic Eoin, Máirin. 2004. “'Severed Heads and Grafted Tongues': The Language Question in Modern and Contemporary Writing in Irish". Hungarian Journal of English and American Studies 10.1-2: 267-81. .2005. Trén bhFearann Breac: an Díláithriú Cultúir agus Nualitríocht na Gaeilge. Baile Átha Cliath: Cois Life.

O'Connor, Joseph. 1996. Sweet Liberty: Travels in Irish America. Boulder, CO: Roberts Rinehart.

Ó Flatharta, Antoine.1990. Grásta i Meiriceá. Indreabhán, Conamara: Cló Iar-Chonnachta. 1993. Grace in America. Unpublished MSS. Revised 29 Sept.-12 Oct. 1998. An Solas Dearg. Indreabhán, Conamara: Cló Iar-Chonnachta. 1999. The Prairie Train. New York: Crown.

2005. Hurry and the Monarch. New York: Knopf.

O’Toole, Fintan. 2003 (1996). "NYT Does It Right". Rev. of Strawberries in December. Dir. Brian Brady. National Youth Theatre at the Peacock Theatre. Irish Times. 17 Sept. 1996:10. Rpt. in Critical Moments: Fintan O'Toole on Modern Irish Theatre. Eds. Julia Furey and Redmond O'Hanlon. Dublin: Carysfort. 16972.

Ostler, Nicholas. 2005. Empires of the Word: A Language History of the World. New York: HarperCollins. 
Paul, Kent. 2004. Telephone interview. 30 Nov.

Pope, Roxana. 1994. "Irish American Antics". Rev. of Grace in America. Dir. Philip Howard. Traverse Theatre, Edinburgh. StUdent. 28 Apr. N. p. (cutting: no pag. indicated)

Said, Edward. 1990 (1988). "Yeats and Decolonization". Field Day Theatre Pamphlet. Rpt. in Nationalism, Colonialism, and Literature. Minneapolis: U of Minnesota P. 69-95.

Thomas, Buddy. 2004. Telephone interview. 7 Dec.

Trudgill, Peter. 2000. Sociolinguistics: An Introduction to Language and Society. $4^{\text {th }}$ ed. London: Penguin. Whyte, Elizabeth. 2004. E-mail to the author. 2 Dec. 